\title{
Water depth and feed pellet type effects on growth and feed utilization in the rearing of green turtle (Chelonia mydas Linnaeus, 1758)
}

\author{
Anida Songnui ${ }^{1}$, Karun Thongprajukaew ${ }^{2, *}$, Hirun Kanghae ${ }^{3}$, Jirapan Satjarak ${ }^{2}$ and Kongkiat \\ Kittiwattanawong ${ }^{3}$ \\ 1 Trang Coastal Fisheries Research and Development Center, Trang, Thailand \\ 2 Department of Applied Science, Faculty of Science, Prince of Songkla University, Songkhla, Thailand \\ ${ }^{3}$ Phuket Marine Biological Center, Phuket, Thailand
}

Received 4 January 2017 / Accepted 10 April 2017

\begin{abstract}
The rearing of green turtles (Chelonia mydas Linnaeus, 1758) before their release to natural habitats has been practiced in several countries, whereas little information is available for inferring optimal husbandry protocols. This study aimed to improve the growth performance and feed utilization of posthatching green turtles by varying the water depth $(15$ or $30 \mathrm{~cm})$ and feed pellet type (sinking or floating pellets). The 20 -day-old turtles $(23.49 \pm 0.02 \mathrm{~g}$ initial body weight) were subjected to a $2 \times 2$ factorial experiment ( 3 replications with 5 animals per tank) over a two-month duration. Growth, feed utilization, fecal digestive enzymes and hematological parameters were recorded to evaluate the effects of different treatments. No mortality was observed in any treatment group. Turtles reared in $15 \mathrm{~cm}$ water depth and fed with floating pellets exhibited superior growth (specific growth rate $2.76 \%$ body weight day ${ }^{-1}$ ) and feed utilization (feeding rate $1.42 \%$ body weight day $^{-1}$, feed conversion ratio $0.61 \mathrm{~g}$ feed $\mathrm{g} \mathrm{gain}^{-1}$, protein efficiency ratio $3.76 \mathrm{~g}$ gain g protein ${ }^{-1}$ ), relative to the other treatments. This treatment improved the utilization of nutrients by modulating trypsin specific activity but had no negative effects on hematological characteristics. Overall these findings indicate that the rearing program of post-hatching green turtles should be run with about $15 \mathrm{~cm}$ water depth and the preferred type of feed is floating pellets. These preferred conditions can also be applied in public displays, such as zoos or aquaria.
\end{abstract}

Keywords: Green turtle / Water depth / Feed pellet / Digestive enzyme / Rearing

\section{Introduction}

The head-starting of hatchling and juvenile green turtles (Chelonia mydas Linnaeus, 1758) before subsequent release into the wild has been practiced in several countries. Such conservation practices address concerns about ongoing destruction and overexploitation of this species while the restoration of the turtle populations in natural ecosystem, through head-started program, is an expected result (Bell et al., 2005; Fontaine and Shaver, 2005; Mitrus, 2005). Under ex situ captivity programs, relatively little is known about the appropriate environmental husbandry conditions, in contrast to various economically important species such as the softshelled turtle, Pelodiscus sinensis (FAO, 2016). The rearing facilities significantly affect the maintenance of sea turtles in research and conservation efforts, in public displays, or in other cases (Higgins, 2003).

\footnotetext{
* Corresponding author: karun.t@psu.ac.th
}

Various water depths have been used on rearing juvenile turtles in captivity programs (Fontaine et al., 1985; Chen et al., 2007; Wang and Huang, 2015). This parameter might affect the surface feeding behavior, which is preferred by the juveniles (Kanghae et al., 2014a). The older turtles feed within the water column and have benthic feeding habits, enabled by gained buoyancy control and ability to dive to the sea bottom (Bolten, 2003). Recently, varying the water depth has been reported to have significant effects on the survival and growth of Nile tilapia, Oreochromis niloticus (Abdel-Aal, 2008; Ali et al., 2013), as well as on their feed utilization and body proximate chemical composition (El-Sayed et al., 1996). A self-feeding trigger has also been observed, as rainbow trout (Oncorhynchus mykiss) can have improved growth when feeding at $1 \mathrm{~cm}$ below the water surface, rather than at mid-water about $35 \mathrm{~cm}$ below the surface (Noble et al., 2007).

Commercial floating fish pellets are commonly used to feed green turtles (WSPA, 2012; Price et al., 2013; Kanghae et al., 2014a, 2014b, 2017), no experimental comparative information is available on the preferred pellet characteristics 
(sinking or floating type). The type of feed pellets has been reported to affect the stereotypic surface, swimming activity and feed intake of halibut, Hippoglossus hippoglossus (Kristiansen and Fernö, 2007). However, some species such as largemouth bass (Micropterus salmoides) have the flexibility to accept or acclimatize to various pellet characteristics, without negative effects on the feeding performance (Tidwell et al., 2015). This might be associated with the water depth and the rearing environment, as suggested by the known feeding behaviors of turtles.

The main purpose of this study was to determine near optimal conditions for the husbandry of post-hatching green turtles, by assessing growth, feed utilization, fecal digestive enzyme activities and hematological parameters. In the study, the water depth and feed pellet type were the key factors when rearing green turtles. Our investigation was conducted in accordance with protection of the target species by the International Union for Conservation of Nature (IUCN), the Convention on International Trade in Endangered Species of Wild Fauna and Flora (CITES), and Thailand's Wildlife Preservation and Protection Act. Only non-invasive techniques without ethical concerns were used to evaluate the turtles' nutritional responses. The feed utilization was tracked by the specific activity of the main fecal digestive enzymes (Kanghae et al., 2014b, 2017). The findings from this study might be useful to improve the head-starting programs of green turtles by the government sector, as well as to improve the conditions in public displays such as zoos or aquaria.

\section{Materials and methods}

\subsection{Experimental animals}

One hundred and twenty eggs were collected from a tagged turtle $(88 \mathrm{~cm}$ curved carapace width and $99 \mathrm{~cm}$ curved carapace length), under the head-started conservation program at Huyong Island, Similan Islands National Park, Phang-Nga, Thailand, by Third Naval Area Command, Royal Thai Navy. The 103 turtles hatched after a 60-day incubation period at 28$30{ }^{\circ} \mathrm{C}$ for in a sandpit. The new hatchlings were reared in fiberglass tanks $(1.5 \mathrm{~m} \times 0.8 \mathrm{~m} \times 0.8 \mathrm{~m}$, with $15 \mathrm{~cm}$ sea water depth) for 20 days, until complete absorption of the yolk-sac.

\subsection{Experimental procedure}

The $2 \times 2$ factorial experiments were performed by randomly distributing five hatchlings $(23.49 \pm 0.02 \mathrm{~g}$ body weight (BW), $4.38 \pm 0.02 \mathrm{~g}$ straight carapace width (SCW) and $5.26 \pm 0.03 \mathrm{~g}$ straight carapace length (SCL)) to each fiberglass tank ( $60 \mathrm{~cm}$ width $\times 30 \mathrm{~m}$ length) with either 15 or $30 \mathrm{~cm}$ water level. Varying water depths were chosen from few previous reports in sea turtles (Fontaine et al., 1985; Chen et al., 2007; Wang and Huang, 2015). They were fed ad libitum with commercial floating or sinking feed pellets for marine carnivorous fish (Charoen Pokphand PCL., Samut Sakhon, Thailand) with almost identical chemical composition (Table 1). Both pellet types (4.5-5.5 mm diameter) were made using the same ingredients but different pelleting processes. Both types of feed pellets were pre-soaked in water
Table 1. The proximate chemical compositions of feed pellets used when rearing green turtles. The analysis was performed in triplicate and the results are expressed as $\mathrm{g} \mathrm{kg}^{-1}$ on DM basis.

\begin{tabular}{|c|c|c|}
\hline Chemical composition $^{\mathrm{a}}$ & Sinking pellet ${ }^{\mathrm{b}}$ & Floating pellet ${ }^{\mathrm{b}}$ \\
\hline Moisture & 75.9 & 68.8 \\
\hline $\mathrm{CP}(\mathrm{DM})$ & 474.1 & 466.8 \\
\hline Crude lipid (DM) & 85.5 & 80.8 \\
\hline Crude fiber (DM) & 23.4 & 29.4 \\
\hline Ash (DM) & 117.7 & 111.5 \\
\hline $\operatorname{NFE}(\mathrm{DM})^{\mathrm{b}}$ & 299.3 & 311.5 \\
\hline $\mathrm{GE}\left(\mathrm{kcal} \mathrm{kg}^{-1} \mathrm{DM}\right)$ & 4785.2 & 4774.5 \\
\hline
\end{tabular}

${ }^{\mathrm{a}} \mathrm{CP}$, crude protein; DM, dry matter; NFE, nitrogen free extract; GE, gross energy.

${ }^{\mathrm{b}}$ Commercial floating or sinking feed pellets for marine carnivorous fish (Charoen Pokphand PCL., Samut Sakhon, Thailand).

$(1: 0.6 \mathrm{w} / \mathrm{v}$ ratio of feed/water) for $60 \mathrm{~min}$, for improving feed utilization (Kanghae et al., 2017), prior to the feeding twice a day (at 09.30 and $16.00 \mathrm{~h}$ ). The studies were conducted indoors over a two-month duration, under a 12-h light/12-h dark photoperiod. The water was renewed daily before the first feeding. The ranges of water quality parameters during the experiment were flexible within a range: $\mathrm{pH}$ 8.05-8.10, temperature $27-28^{\circ} \mathrm{C}$, salinity $31-32 \mathrm{ppt}$ and ammonianitrogen $0.131-0.258 \mathrm{mg} \mathrm{L}^{-1}$. Mortality and morbidity of the turtles were monitored daily over the whole duration of the study. All the turtles were protected against disease or parasite infections by dipping in $60 \mathrm{mg} \mathrm{L}^{-1}$ polyvinylpyrrolidoneiodine for $20 \mathrm{~min}$ and then cleaning them with a soft sponge, every other week (Kanghae et al., 2014a). The amount of the consumed feed was estimated as the difference of feed pellets offered and those recovered as uneaten, after oven drying at $60{ }^{\circ} \mathrm{C}$ until constant weight. This estimation was used to calculate feeding rate (FR), feed conversion ratio (FCR) and protein efficiency ratio (PER). BW, SCW and SCL, as well as the above feed utilization parameters, were recorded every other week.

\subsection{Proximate chemical analysis}

The experimental feed pellets were analyzed for their chemical compositions, including crude protein (CP), crude lipid, crude fiber and ash, according to standard methods of AOAC (2005). All analyses were performed in triplicates and are reported on dry matter (DM) basis. Some calculations were carried out as follows (Anand et al., 2014):

$$
\begin{aligned}
& \text { Nitrogen free extract }\left(\mathrm{NFE}, \mathrm{g} \mathrm{kg}^{-1}\right) \\
& \quad=1000-(\mathrm{CP}+\text { crude lipid }+ \text { crude fiber }+ \text { ash }),
\end{aligned}
$$

$$
\begin{aligned}
\text { Gross energy }\left(\mathrm{GE}, \mathrm{kcal} \mathrm{kg}^{-1}\right) & =[(\mathrm{CP} \times 5.6)+(\text { crude lipid } \\
& \times 9.44)+(\text { crude fiber } \times 4.1) \\
& +(\mathrm{NFE} \times 4.1)] .
\end{aligned}
$$




\subsection{Fecal digestive enzyme activities}

\subsubsection{Digestive enzyme extraction}

At the end of the experiment, all turtles were starved for $24 \mathrm{~h}$ and then the feces ( $n=3$ per treatment) were quickly collected by dip net. The feces were rinsed carefully by cold distilled water, homogenized in distilled water (1:5 w/v of feces to water) using a micro-homogenizer (THP-220; Omni International, Kennesaw GA, USA), centrifuged, and the supernatant was collected, as described by Kanghae et al. (2017).

\subsubsection{Determination of protein concentration}

The protein concentration $\left(\mathrm{mg} \mathrm{mL}^{-1}\right)$ in crude enzyme extract was determined based on the method of Lowry et al. (1951), using the Folin-Ciocalteu reagent. Bovine serum albumin (BSA) was used as the protein standard. These values were used to calculate the specific activity of fecal digestive enzymes (U mg protein ${ }^{-1}$ ).

\subsubsection{Digestive enzyme activity assay}

All the fecal digestive enzyme assays were performed at near optimal conditions as described in Kanghae et al. (2017). One unit (U) of each enzyme activity is defined as the amount that catalyzes the conversion of $1 \mu \mathrm{mol}$ substrate under specified conditions. The pepsin activity was assayed according to method of Rungruangsak and Utne (1981), using $2 \%(\mathrm{w} / \mathrm{v})$ casein as the substrate. The amount of product was measured spectrophotometrically at $720 \mathrm{~nm}$ against standard $L$-tyrosine.

The trypsin (EC 3.4.21.4) and chymotrypsin (EC 3.4.21.1) activities were assayed according to Rungruangsak-Torrissen et al. (2006), using $1.25 \mathrm{mM} N$-benzoyl- $L$-Arg- $p$-nitroanilide (BAPNA) and $0.10 \mathrm{M} N$-succinyl-Ala-Ala-Pro-Phe- $p$-nitroanilide (SAPNA) as the substrates, respectively. The product of each enzyme was detected spectrophotometrically at $410 \mathrm{~nm}$, by comparing to the linear response concentration range of standard $p$-nitroanilide.

The amylase activity was assayed based on Areekijseree et al. (2004), using 2\% (w/v) soluble starch as substrates. Reducing sugars were stained by 3,5-dinitrosalicylic acid and then quantified spectrophotometrically at $540 \mathrm{~nm}$, by comparison to standard maltose.

The lipase activity was assayed based on the method of Winkler and Stuckmann (1979) with some modifications. The reaction mixture contained $200 \mu \mathrm{L}$ of $0.01 \mathrm{M} p$-nitrophenyl palmitate, $800 \mu \mathrm{L}$ of $\mathrm{Na}_{2} \mathrm{CO}_{3}-\mathrm{NaHCO}_{3}$ buffer $(\mathrm{pH}$ 9) and $10 \mu \mathrm{L}$ of crude enzyme. Then $250 \mu \mathrm{L}$ of $1 \mathrm{M} \mathrm{Na}_{2} \mathrm{CO}_{3}$ was added after $15 \mathrm{~min}$ incubation, and centrifuging at $13000 \times \mathrm{g}$ was done for $15 \mathrm{~min}$. The supernatant was collected and the amount of product was measured in comparison to $p$-nitrophenol standard at $410 \mathrm{~nm}$.

\subsection{Hematological parameters}

Blood samples ( $n=3$ pooled samples per treatment) were taken from turtles, which were starved for $24 \mathrm{~h}$, with $1 \mathrm{~mL}$ syringes ( $23 \mathrm{G}$ needle size) from the dorsal cervical sinus. The samples were mixed into tubes containing $1 \mathrm{mgEDTA} \mathrm{mL}^{-1}$ blood and were kept refrigerated at $4{ }^{\circ} \mathrm{C}$. All analyses were done within $24 \mathrm{~h}$. Hemoglobin and packed cell volume (hematocrit) were determined according to the method of Larsen and Snieszko (1961). Red (RBC) and white (WBC) blood cell counts from diluted samples were determined based on the method of Blaxhall and Daisley (1973). Blood urea nitrogen (BUN), creatinine, uric acid, alkaline phosphatase (ALP), alanine transaminase (ALT) and aspartate transaminase (AST) were determined using a commercial diagnostic kit (PZ Cormay S.A. Company, Lomianki, Poland).

\subsection{Statistical analysis and calculations}

The $2 \times 2$ factorial design of experiments was conducted randomized. Twelve tanks were designated as the experimental units, each one containing 5 turtles. All data were analyzed using SPSS Version 14 (SPSS Inc., Chicago, USA), and the results were summarized as tank mean \pm SEM. Significances of each factor (water depth and pellet type) and their interaction were tested with two-way ANOVA, with the significance threshold set as $P<0.05$. The relationship between feed utilization and specific activities of fecal digestive enzymes was assessed from Pearson correlation coefficients $(r)$. Calculations of growth performance and feed utilization characteristics were carried out as follows:

$$
\begin{aligned}
& \text { Survival }(\%)= 100 \times(\text { Final number of turtles } / \\
&\text { initial number of turtles }),
\end{aligned}
$$

$$
\begin{aligned}
& \text { Body condition index }\left(\mathrm{BCI}, \mathrm{kg} \mathrm{cm}^{-1}\right) \\
& =\left[\mathrm{BW}(\mathrm{kg}) / \text { carapace length }(\mathrm{cm})^{3}\right] \times 10^{4}, \\
& \text { Specific growth rate }\left(\mathrm{SGR}, \% \mathrm{BW} \text { day }^{-1}\right) \\
& \left.=100 \times\left[\left(\ln W_{t}-\ln W_{0}\right) / t-t_{0}\right)\right],
\end{aligned}
$$

where $W_{t}=$ mean weight $(\mathrm{g})$ at day $t, W_{0}=$ mean weight $(\mathrm{g})$ at day $t_{0}$.

$$
\mathrm{FR}\left(\% \mathrm{BW} \mathrm{day}^{-1}\right)=100 \times C /\left[\left(W_{0}+W_{t}\right) / 2\right] / t,
$$

where $C=$ daily feed consumption $(\mathrm{g}), W_{0}=$ initial $\mathrm{BW}(\mathrm{g})$, $W_{t}=$ final $\mathrm{BW}(\mathrm{g}), t=$ feeding duration (day).

$$
\begin{gathered}
\text { FCR }\left(\text { g feed g gain }^{-1}\right)=\text { Dry feed consumed }(\mathrm{g}) / \\
\text { wet weight gain }(\mathrm{g}),
\end{gathered}
$$

$$
\begin{gathered}
\operatorname{PER}\left(\text { g gain g }_{\text {protein }}^{-1}\right)=\text { Wet weight gain }(\mathrm{g}) / \\
\text { protein intake }(\mathrm{g}) .
\end{gathered}
$$

\section{Results}

\subsection{Chemical composition of experimental feed pellets}

The floating and sinking feed pellets were similar in their chemical composition (Table 1). The feeds contained $471 \mathrm{~g} \mathrm{~kg}^{-1}$ $\mathrm{CP}, 83 \mathrm{~g} \mathrm{~kg}^{-1}$ crude lipid, $26 \mathrm{~g} \mathrm{~kg}^{-1}$ crude fiber, $115 \mathrm{~g} \mathrm{~kg}^{-1}$ ash, $305 \mathrm{~g} \mathrm{~kg}^{-1} \mathrm{NFE}$ and $4780 \mathrm{kcal} \mathrm{kg}^{-1}$ on average, on DM basis. 
Table 2. Growth performance and feed utilization of post-hatching green turtles reared under different water depths ( $15 \mathrm{or} 30 \mathrm{~cm})$ and fed with commercial feed pellets (sinking or floating type). ${ }^{\text {a }}$ The data (mean $\pm \mathrm{SEM}$ ) are for turtles sampled at the end of the experiment.

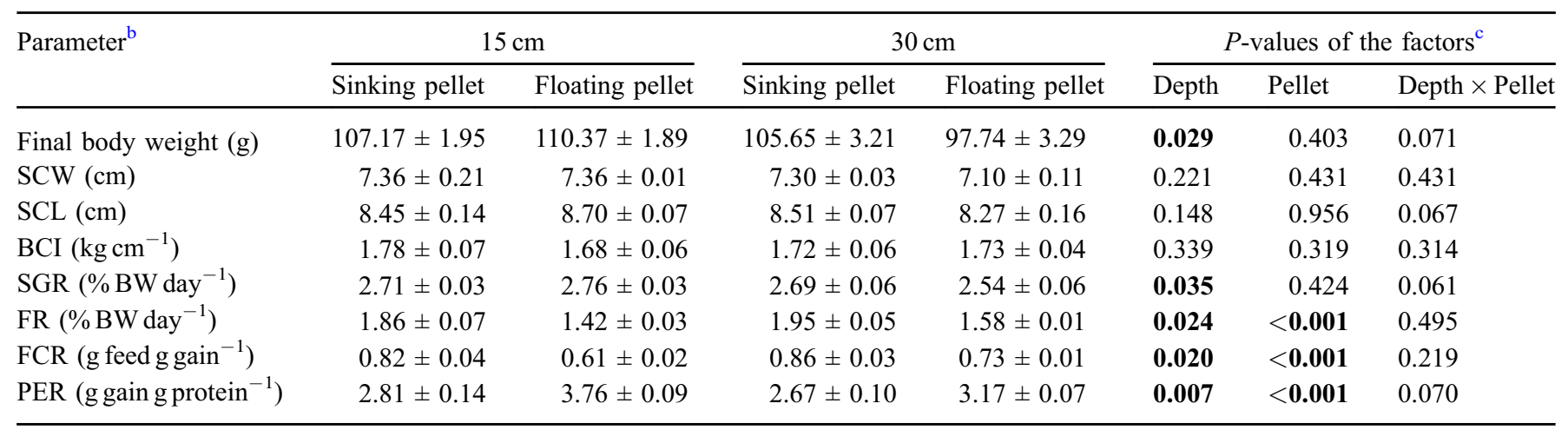

${ }^{\mathrm{a}}$ Commercial floating or sinking feed pellets for marine carnivorous fish (Charoen Pokphand PCL., Samut Sakhon, Thailand).

${ }^{\mathrm{b}} \mathrm{SCW}$, straight carapace width; SCL, straight carapace length; BCI, body condition index; SGR, specific growth rate; BW, body weight; FR, feeding rate; FCR, feed conversion ratio; PER, protein efficiency ratio.

${ }^{\mathrm{c}}$ Significant values are indicated by bold type $(P<0.05)$.

\subsection{Survival, growth and feed utilization}

No mortality was observed in any treatment group during the period of 8 weeks. Water depth had significant effects on final BW, SGR, FR, FCR and PER $(P<0.05$, Table 2$)$. The effects of feed pellet type were similar, except for a response in final BW and SGR. The SCW, SCL and BCI were unaffected by either water depth or pellet type, or their interaction $(P>0.05)$. Based on the observed trends above, turtles reared at $15 \mathrm{~cm}$ water depth and fed by floating pellets had positive effects on growth and feed utilization, relative to the other treatments.

\subsection{Specific activity of fecal digestive enzymes}

Feeding turtles with floating pellets significantly decreased the specific activity of trypsin, relative to feeding with sinking pellets (Table 3). Based on two-way ANOVA, the specific activities of pepsin, chymotrypsin, amylase and lipase were not significantly affected by either water depth, pellet type, or their interaction. The interaction significantly affected only trypsin specific activity.

Pearson correlation analysis indicates significant positive relationships of FR and FCR with specific activities of trypsin and amylase (Table 4). Contrariwise, a negative relationship was observed between the trypsin specific activity and the PER value. Significant relationships were also observed between the specific activity of pepsin and those of amylase and lipase.

\subsection{Hematological parameters}

Water depth, feed pellet type or their interaction did not affect packed cell volume, hemoglobin, RBC, WBC, lymphocyte, BUN, creatinine, uric acid, ALP, ALT or AST (Table 5). Interaction of the factors had a significant effect only on the heterophil:lymphocyte ratio (HLR), which had its highest value in turtles reared at $30 \mathrm{~cm}$ water depth that were fed with sinking pellets.

\section{Discussion}

Low survival, inferior growth and feed utilization, as well as poor health status are common problems in captivity programs of sea turtles. In the current study, the water depth significantly affected the BW and the SGR of green turtles. Superior results were obtained when turtles were reared at $15 \mathrm{~cm}$ seawater depth, as compared to a depth of $30 \mathrm{~cm}$. This water level is similar to the $20 \mathrm{~cm}$ height of plastic cylindrical containers for rearing juvenile soft-shelled turtles (Wang and Huang, 2015), and to the $22 \mathrm{~cm}$ height of containers for individual sea turtles (Loma Plastics Inc., Fort Worth, TX, USA). Chen et al. (2007) reared juvenile soft-shelled turtles at a fixed depth of $30 \mathrm{~cm}$ while the husbandry of hatchling to yearling Kemp's ridley sea turtles (Lepidochelys kempi) used a depth of $30.5 \mathrm{~cm}$ (Fontaine et al., 1985). The Nile tilapia has faster growth rate when reared at $100-175 \mathrm{~cm}$ depth than at $75 \mathrm{~cm}$ depth (Abdel-Aal, 2008; Ali et al., 2013); another report shows $100-200 \mathrm{~cm}$ depth favorable, as compared to $50 \mathrm{~cm}$ or $300 \mathrm{~cm}$ depths (El-Sayed et al., 1996). Therefore, the preferable water depth varies by species (along with other potential factors, such as maturity) and the optimal form of conditions in the current study may help to improve turtle husbandry. Moreover, the positive effect on high growth rate may also affect the attitudes regarding rearing duration, which might lead to alternative conservation practices for the government sector; shortening the captivity duration but providing body weight as purpose at one year of rearing.

The early juvenile stage probably feeds on the surface and within the water column, and may later develop a benthic feeding habit once the turtle has gained buoyancy control and can dive to the sea bottom (Bolten, 2003). The floating tendency of these feeds provides an opportunity for food intake at the water surface, preferred by the juveniles (Kanghae et al., 2014a). In addition, based on a point of view of energy consumption, turtles need to float to the surface to breathe which means they are in need of energy. This may be part of the reason why turtles in $30 \mathrm{~cm}$ group had a higher FR but lower 
Table 3. Specific activities of fecal digestive enzymes in post-hatching green turtles when reared under different water depths (15 and $30 \mathrm{~cm})$ and fed with commercial feed pellets (sinking or floating type). ${ }^{a}$ The data (mean $\pm \mathrm{SEM}$ ) are for turtles sampled at the end of the experiment.

\begin{tabular}{|c|c|c|c|c|c|c|c|}
\hline Parameter & \multicolumn{2}{|c|}{$15 \mathrm{~cm}$} & \multicolumn{2}{|c|}{$30 \mathrm{~cm}$} & \multicolumn{3}{|c|}{$P$-values of the factors ${ }^{\mathrm{b}}$} \\
\hline Pepsin (mU mg protein $\left.{ }^{-1}\right)$ & $13.44 \pm 0.58$ & $8.00 \pm 1.96$ & $12.30 \pm 1.89$ & $11.02 \pm 2.95$ & 0.655 & 0.137 & 0.335 \\
\hline Trypsin (mU mg protein $\left.{ }^{-1}\right)$ & $211.59 \pm 0.03$ & $56.65 \pm 3.78$ & $172.07 \pm 17.37$ & $97.21 \pm 14.17$ & 0.969 & $<\mathbf{0 . 0 0 1}$ & 0.017 \\
\hline Chymotrypsin $\left(\mathrm{mU} m g\right.$ protein $\left.^{-1}\right)$ & $24.46 \pm 6.67$ & $18.56 \pm 3.47$ & $19.50 \pm 4.84$ & $16.38 \pm 3.90$ & 0.503 & 0.380 & 0.869 \\
\hline Amylase (U mg protein $\left.{ }^{-1}\right)$ & $1.48 \pm 0.25$ & $0.89 \pm 0.01$ & $1.66 \pm 0.39$ & $1.17 \pm 0.09$ & 0.467 & 0.052 & 0.708 \\
\hline
\end{tabular}

${ }^{a}$ Commercial floating or sinking feed pellets for marine carnivorous fish (Charoen Pokphand PCL., Samut Sakhon, Thailand).

${ }^{\mathrm{b}}$ Significant values are indicated by bold type $(P<0.05)$.

Table 4. Pearson correlation coefficients $(r)^{\mathrm{a}}$ among feed utilization parameters and specific activities of the fecal digestive enzymes. The values were calculated from twelve experimental cases $(n=12)$.

\begin{tabular}{llllllll}
\hline Parameter $^{\mathrm{b}}$ & FR & FCR & PER & Pepsin & Trypsin & Chymotrypsin & Amylase \\
\hline FR & 1 & & & & & & \\
FCR & $-0.978^{* *}$ & 1 & & & & & \\
PER & $-0.968^{* *}$ & $-0.993^{* *}$ & 1 & & & & \\
Pepsin & 0.539 & 0.522 & -0.499 & 1 & & \\
Trypsin & $0.675^{*}$ & $0.645^{*}$ & $-0.641^{*}$ & 0.493 & 1 & & 1 \\
Chymotrypsin & 0.238 & 0.162 & -0.144 & 0.505 & 0.274 & 1 & 0.234 \\
Amylase & $0.585^{*}$ & $0.604^{*}$ & -0.528 & $0.734^{* *}$ & 0.429 & 0.035 & 1 \\
Lipase & 0.252 & 0.242 & -0.211 & $0.625^{*}$ & 0.175 & 0.011 \\
\hline
\end{tabular}

a $* P<0.05, * * P<0.01$

${ }^{\mathrm{b}}$ FR, feeding rate; FCR, feed conversion ratio; PER, protein efficiency ratio.

Table 5. Hematological parameters of post-hatching green turtles reared under different water depths ( 15 and $30 \mathrm{~cm})$ and fed with commercial feed pellets (sinking or floating type). ${ }^{\mathrm{a}}$ The data (mean $\pm \mathrm{SEM}$ ) are for turtles sampled at the end of the experiment.

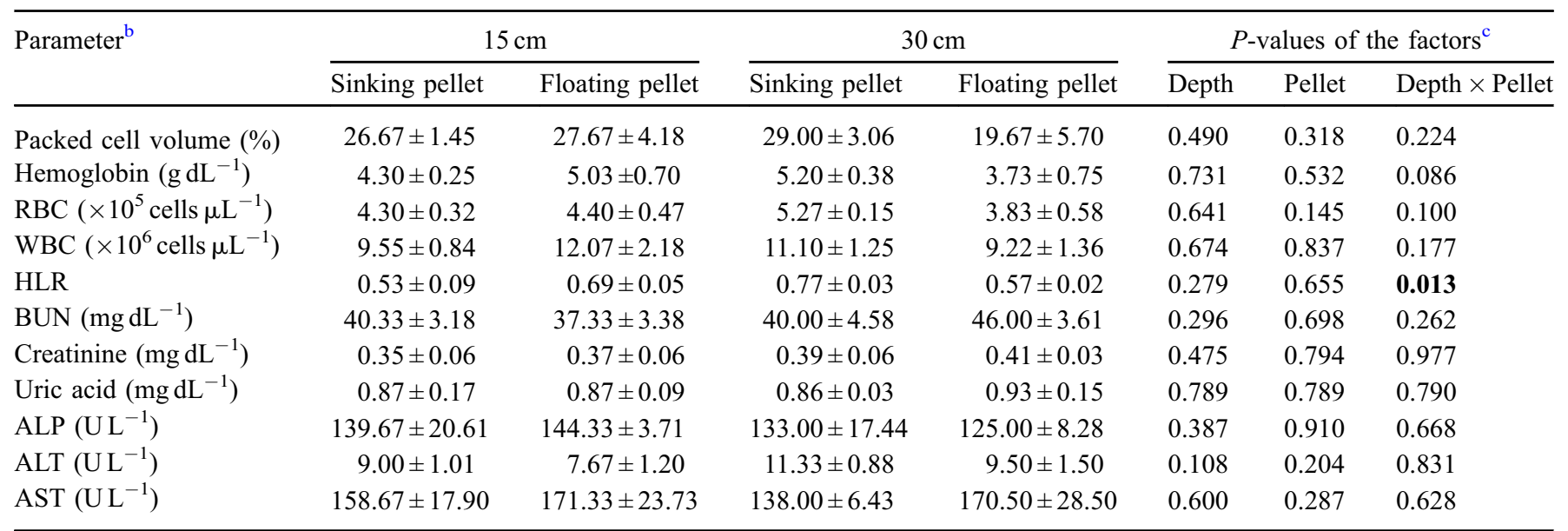

${ }^{a}$ Commercial floating or sinking feed pellets for marine carnivorous fish (Charoen Pokphand PCL., Samut Sakhon, Thailand).

${ }^{\mathrm{b}} \mathrm{RBC}$, red blood cells; WBC, white blood cells; HLR, heterophil:lymphocyte ratio; BUN, blood urea nitrogen; ALP, alkaline phosphatase; ALT, alanine transaminase; AST, aspartate transaminase.

${ }^{\mathrm{c}}$ Significant values are indicated by bold type $(P<0.05)$.

SGR compared with that of $15 \mathrm{~cm}$ group. Therefore, reduction of the water depth combined with floating pellets supports the feeding biology or feeding behaviors of green turtles in their early stages. Generally, the commercial feeds used to rear green turtles contain 40-50\% protein (Hadjichristophorou and Grove, 1983; Kanghae et al., 2014a, 2014b, 2017). These feeds are floating pellets, and are also used in fish rearing (WSPA, 2012; Price et al., 2013; Kanghae et al., 2014a, 2014b, 2017). 
While similar chemical compositions were observed for the two pellet types, the pelleting process could affect growth performance and feed utilization by modifying the nutritional and physical qualities of the feed ingredients (Behnke, 1996; Booth et al., 2000). On producing the floating pellets, the heat and mixing time in the extruder can increase the degree of gelatinization (Lundblad et al., 2011), which contributes to the digestibility of starch (Robinson et al., 2004). The positive relationship between specific activity of amylase, FR, and FCR in the current study also supported the aspect. The sinking pellets are produced with a mincer that can partially gelatinize starch. This matches well with the improved growth performance of giant tiger prawns (Penaeus monodon) when fed extruded feed pellets, as opposed to pellets produced with a mincer (Gokulakrishnan and Bandyopadhyay, 1995). Differences in growth and feed utilization are also observed in olive flounder (Paralichthys olivaceus) on comparing sinking pellets and floating extruded pellets as the feed (Lee and Pham, 2010). In addition, the chemical composition, such as amino acids, might markedly change during the pelleting processes (high temperature and high pressure) for floating pellets. Some of the temperature-sensitive constituents (e.g. fatty acids and vitamins) may also be destroyed. Comparison between physical properties and fine chemical constituents should be further investigated.

SGR of green turtles in the current study $\left(2.76 \% \mathrm{BW} \mathrm{day}^{-1}\right.$ or $1.37 \mathrm{~g} \mathrm{day}^{-1}$ ) is similar to that observed in soft-shelled turtle $\left(2.91 \% \mathrm{BW} \mathrm{day}^{-1}\right)$ (Zhou et al., 2013). The higher growth rate was reported in some species such as $3 \mathrm{~g}$ day $^{-1}$ of captive Kemp's ridley turtles during the first year of life (Caillouet, 1984 ) or range $2.33-44.11 \mathrm{~g} \mathrm{day}^{-1}$ of wild hawksbill sea turtles, Eretmochelys imbricata (Hawkes et al., 2014). Differences in observed growth rate are varied with species, age, genetics, rearing condition and nutritional quality of diet. The best conditions in the current study improved the feed utilization of reared turtles. The feed rations of soft-shelled turtles at $4 \% \mathrm{BW} \mathrm{day}^{-1}$ (Lei, 2006) are larger than those of green turtles from the current study $\left(1.4 \% \mathrm{BW} \mathrm{day}^{-1}\right)$. The feed rations from $1.2 \%$ to $2.0 \%$, or from $1.5 \%$ to $1.7 \% \mathrm{BW}$ $\mathrm{day}^{-1}$, are used for Kemp's ridley sea turtles (Higgins, 2003) or for snapping turtles, Chelydra serpentina (Mayeaux et al.,

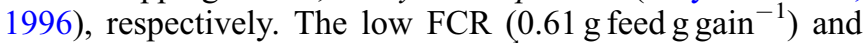
the high PER ( 3.76 g gain g protein $^{-1}$ ) suggest that the turtles utilized the feed relatively well compared to the other treatments. This high capacity of turtles to utilize feed is similar to African catfish, Clarias gariepinus, with observed

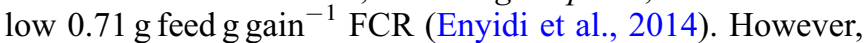
the pellet feed amounts are expressed on dry basis, while a large fraction of the weight gain in turtles is water trapped in the tissues. The rapid satiation of turtles fed with pre-soaked pellets supports reduced FR, while improvements in the physicochemical properties of the pellets, as well as in the digestive efficiency of the turtles, directly influences FCR and PER (Kanghae et al., 2017).

Unobtrusive and non-invasive approaches were used for studying nutritional responses in this endangered species. Córdova-Murueta et al. (2003) reported a close relationship between digestive enzymes extracted from feces and from the mid gut of whiteleg shrimp (Penaeus vannamei). These enzymes are produced by the gastrointestinal tract or by accessory glands, and are secreted into gut lumen. After digestion, the enzymes are excreted in the feces, and are protected by membranes that prevent leakage (CórdovaMurueta et al., 2003). Therefore, these enzymes, as well as physicochemical characteristic of the feces, could be used for assessing feed utilization efficiency in green turtles, although without performing digestibility trials (Kanghae et al., 2014b, 2017; Thongprajukaew et al., 2016).

Amylase and lipase specific activities did not vary with water depth or pellet type. This suggests that all the turtles had similar access to carbohydrates and lipids in their feed. Among the three observed proteolytic enzymes, only trypsin specific activity was affected by pellet type. This enzyme acts as an activator regulating zymogen, which further contributes about $40-50 \%$ of the overall intestinal protein digestion (Eshel et al., 1993). Its activity decreased with increasing PER and vice versa for FR and FCR, indicating that the production of this enzyme is sufficient to digest the proteins in the floating pellets. This hypothesis matches well with the decrease in both FR and FCR in the current study, even though the turtles were fed for ad libitum intake. Similar observations have been reported for yellowtail kingfish, Seriola lalandi (Miegel et al., 2010) and for turbot, Scophthalmus maximus (Xian et al., 2013): decreased feed intake can significantly decrease the protease activity. In addition, the production of floating pellets may not be only improving the degree of starch gelatinization; it can directly denature dietary proteins (Sansuwan et al., 2017). Decreased trypsin activity in the preferred treatment could allow the turtles to use more energy in anabolic processes, such as growth, rather than in catabolism. Upregulation of trypsin activity in turtles fed with sinking pellets might be associated with the less denatured proteins, which require more trypsin during digestion. There were no physiological responses in pepsin and chymotrypsin that would correlate with feed utilization. Similarly, the pepsin specific activity and the feed quality did not correlate in rainbow trout, Salmo gairdneri (Rungruangsak and Utne, 1981). However, the expression of pepsin significantly correlated with both amylase and lipase activities. This association among the three groups of digestive enzymes indicates the important role of stomach protein digestion, in improving carbohydrate and lipid digestion in the intestine. Similarly, dietary carbohydrate appears to be necessary for good growth and protein utilization in fish (Wilson, 1994). As for chymotrypsin, it plays a major role when growth is limited or depressed (Rungruansak-Torrissen et al., 2006), but in the current study we have linear growth performance. Different activities of these enzymes might be due to different physiological responses, or to different sensitivities in the responses.

The various parameters, including seasonal changes, age, sex, geographic location, physiological responses and reproductive status, also influence the hematological response of Chelonians (Zhang et al., 2011). The HLR is an important marker, indicating stress response in the turtles (Chen et al., 2007). This indicator increased in yellow-blotched sawback (Graptemys flavimaculata), when they lived in a disturbed site, compared to an undisturbed site (Selman et al., 2013). In the current study, the interaction of water depth and pellet types should be recorded as important factors to husbandry, with effects on the HLR. Rearing in deeper water can cause stress, because the post-hatching turtles have difficulty diving along the water column to ingest the pellets on bottom. On the other 
hand, increased stocking density may translate into more intense stress from increased competition for feed (Chen et al., 2007). However, there were no significant changes in the HLR of turtles reared in preferred conditions as compared to the other three groups $(P>0.05)$. The other steady parameters, as well as behavioral observations regarding swimming and feeding, also corroborate that this treatment had no negative effects on the hematological response. However, health monitoring in order to improve the husbandry quality should be of interest.

\section{Conclusions}

The water depth and feed pellet type had significant effects on growth performance of post-hatching green turtles. Modulation of key digestive enzymes played an integral role in improving feed utilization. There were no negative effects on hematological characteristics in reared turtles. The preferred conditions $(15 \mathrm{~cm}$ water depth and floating feed pellets) of the current study may support the high quality production of head-started green turtles, before their release to the natural ecosystem, as well as the rearing of turtles for public displays in zoos or aquaria. However, health assessment is still needed for supporting the animal welfare under this captivity program.

Acknowledgements. Financial and facility support were provided by the Phuket Marine Biological Center. The authors are grateful to the Third Naval Area Command, Royal Thai Navy, for kindly providing green turtle eggs. Special thanks to Charoen Pokphand Foods PCL., for kindly providing two types of feed pellets. We also gratefully acknowledge the Publication Clinic, Research and Development Office and the International Relations Unit, Faculty of Science, Prince of Songkla University, for their assistance in manuscript preparation.

\section{References}

Abdel-Aal MM. 2008. Effects of over-wintering and water depth on growth performance of Nile tilapia (Oreochromis niloticus). In: Proceedings of the 8th International Symposium on Tilapia in Aquaculture. Cairo: The Central Laboratory for Aquaculture Research, Ministry of Agriculture and Land Reclamation, pp. 297-306

Ali NAM, El-Feky AMI, Khouraiba HM, El-Sherif MS. 2013. Effect of water depth on growth performance and survival rate of mixed sex Nile tilapia fingerlings and adults. Egypt J Anim Prod 50: 194199.

Anand PSS, Kohli MPS, Kumar S, et al. 2014. Effect of dietary supplementation of biofloc on growth performance and digestive enzyme activities in Penaeus monodon. Aquaculture 418-419: $108-115$.

AOAC. 2005. Official methods of analysis, 18th ed. Washington, DC: Association of Official Analytical Chemists.

Areekijseree M, Engkagul A, Kovitvadhi U, et al. 2004. Temperature and $\mathrm{pH}$ characteristics of amylase and proteinase of adult freshwater pearl mussel, Hyriopsis (Hyriopsis) bialatus Simpson 1900. Aquaculture 234: 575-587.

Behnke KC. 1996. Feed manufacturing technology: current issues and challenges. Anim Feed Sci Technol 62: 49-57.
Bell CDL, Parsons J, Austin TJ, Broderick AC. 2005. Some of them came home: the Cayman Turtle Farm head-starting project for the green turtle Chelonia mydas. Oryx 39: 137-148.

Blaxhall PC, Daisley KW. 1973. Routine haematological methods for use with fish blood. J Fish Biol 5: 771-781.

Bolten AB. 2003. Variation in sea turtle life history patterns: neritic vs. oceanic developmental stages. In: Lutz PL, Musick JA, Wyneken J, eds. The biology of sea turtles, vol. 3. Florida: CRC Press, pp. 243-258.

Booth MA, Allan GL, Warner-Smith R. 2000. Effects of grinding, steam conditioning and extrusion of a practical diet on digestibility and weight gain of silver perch, Bidyanus bidyanus. Aquaculture 182: 287-299.

Caillouet CW. 1984. Essai de prévention de l'extinction de la tortue de Kemp. Les Carnets de Zoologie 44: 28-34.

Chen X, Niu C, Pu L. 2007. Effects of stocking density on growth and non-specific immune responses in juvenile soft-shelled turtle, Pelodiscus sinensis. Aquac Res 38: 1380-1386.

Córdova-Murueta JH, García-Carreño FL, Navarrete-del-Toro MA. 2003. Digestive enzymes present in crustacean feces as a tool for biochemical, physiological, and ecological studies. J Exp Mar Biol Ecol 297: 43-56.

El-Sayed AFM, EI-Ghobashy A, Al-Amoudi M. 1996. Effects of pond depth and water temperature on the growth, mortality and body composition of Nile tilapia, Oreochromis niloticus (L.). Aquac Res 27: 681-687.

Enyidi UD, Pirhonen J, Vielma J. 2014. Effects of sesame seed meal and bambaranut meal on growth, feed utilization and body composition of juvenile African catfish Clarias gariepinus. Iran J Fish Sci 13: 998-1013.

Eshel A, Lindner P, Smirnoff P, Newton S, Harpaz S. 1993. Comparative study of proteolytic enzymes in the digestive tracts of the European sea bass and hybrid striped bass reared in freshwater. Comp Biochem Physiol A: Physiol 106: 627-634.

FAO. 2016. Cultured aquatic species information programme Trionyx sinensis (Weigmann, 1834). Rome: FAO.

Fontaine CT, Marvin KT, Williams TD, et al. 1985. The husbandry of hatchling to yearling Kemp's ridley sea turtles (Lepidochelys kempii). Springfield, VA: National Technical Information Service.

Fontaine CT, Shaver DJ. 2005. Head-starting the Kemp's ridley sea turtle, Lepidochelys kempii, at the NMFS Galveston Laboratory, 1978-1992: a review. Chelonian Conserv Biol 4: 838-845.

Gokulakrishnan P, Bandyopadhyay S. 1995. Formulation and characterisation of some pelleted feeds for Penaeus monodon. Fish Technol 32: 19-24.

Hadjichristophorou M, Grove DJ. 1983. A study of appetite, digestion and growth in juvenile green turtle (Chelonia mydas L.) fed on artificial diets. Aquaculture 30: 191-201.

Hawkes LA, McGowan A, Broderick AC, et al. 2014. High rates of growth recorded for hawksbill sea turtles in Anegada, British Virgin Islands. Ecol Evolut 4: 1255-1266.

Higgins BM. 2003. Sea turtle husbandry. In: Lutz PL, Musick JA, Wyneken J, eds. The biology of sea turtles, vol. 3. Florida: CRC Press, pp. 411-440.

Kanghae H, Ninwat S, Thongprajukaew $\mathrm{K}$, Intongcome A, Kittiwattanawong K. 2014a. Performance of head-started green turtle, Chelonia mydas (Linnaeus 1758) fed a commercial diet. Asian Fish Sci 27: 160-172.

Kanghae H, Thongprajukaew K, Madlee A, Kittiwattanawong K. 2014b. Is artificial feed suitable for juvenile green turtles (Chelonia mydas)? Aquaculture 428-429: 97-103. 
Kanghae H, Thongprajukaew K, Phromkunthong W, Plangsri S, Jatupornpitukchat S, Kittiwattanawong K. 2017. Pre-soaking of the feed pellets: a trick for successful feed utilization in juvenile green turtles (Chelonia mydas Linnaeus, 1758). J Anim Physiol Anim Nutr 101: 329-338.

Kristiansen TS, Fernö A. 2007. Individual behaviour and growth of halibut (Hippoglossus hippoglossus L.) fed sinking and floating feed: evidence of different coping styles. Appl Anim Behav Sci 104: 236-250.

Larsen HN, Snieszko SF. 1961. Comparison of various methods of determination of haemoglobin in trout blood. Prog Fish Cult 23: $8-17$.

Lee SM, Pham MA. 2010. Effects of feeding frequency and feed type on the growth, feed utilization and body composition of juvenile olive flounder, Paralichthys olivaceus. Aquac Res 41: e166-e171.

Lei SJ. 2006. Effects of ration level and feeding frequency on digestibility in juvenile soft-shelled turtle, Pelodiscus sinensis. $J$ Zhejiang Univ Sci B 7: 580-585.

Lowry OH, Rosenbrough NJ, Farr AL, Randall RJ. 1951. Protein measurement with the Folin phenol reagent. J Biol Chem 193: $265-275$.

Lundblad KK, Issa S, Hancock JD, et al. 2011. Effects of steam conditioning at low and high temperature, expander conditioning and extruder processing prior to pelleting on growth performance and nutrient digestibility in nursery pigs and broiler chickens. Anim Feed Sci Technol 169: 208-217.

Mayeaux MH, Culley DD, Reigh RC. 1996. Effects of dietary energy: protein ratio and stocking density on growth and survival of the common snapping turtle Chelydra serpentina.J World Aquac Soc 27: 64-73.

Miegel RP, Pain SJ, van Wettere WHEJ, Howarth GS, Stone DAJ. 2010. Effect of water temperature on gut transit time, digestive enzyme activity and nutrient digestibility in yellowtail kingfish (Seriola lalandi). Aquaculture 308: 145-151.

Mitrus S. 2005. Headstarting in European pond turtles (Emys orbicularis): does it work? Amphibia-Reptilia 26: 333-341.

Noble C, Mizusawa K, Tabata M. 2007. The effect of trigger depth on self-feeder utilisation, growth and the vertical distribution of tankheld rainbow trout Oncorhynchus mykiss (Walbaum). Aquaculture 273: 64-70.

Price ER, Jones TT, Wallace BP, Guglielmo CG. 2013. Serum triglycerides and $\beta$-hydroxybutyrate predict feeding status in green turtles (Chelonia mydas): evaluating a single blood sample method for assessing feeding/fasting in reptiles. J Exp Mar Biol Ecol 439: 176-180.
Robinson EH, Manning BB, Li MH. 2004. Feed and feeding practices. In: Tucker CS, Hargreaves JA, eds. Biology and culture of channel catfish. Atlanta: Elsevier, pp. 324-348.

Rungruangsak K, Utne F. 1981. Effect of different acidified wet feeds on protease activities in the digestive tract and on growth rate of rainbow trout (Salmo gairdneri Richardson). Aquaculture 22: $67-79$.

Rungruangsak-Torrissen K, Moss R, Andresen LH, Berg A, Waagbo R. 2006. Different expressions of trypsin and chymotrypsin in relation to growth in Atlantic salmon (Salmo salar L.). Fish Physiol Biochem 32: 7-23.

Sansuwan K, Kovitvadhi S, Thongprajukaew K, Ozório ROA, Somsueb P, Kovitvadhi U. 2017. Microwave irradiation and pelleting method affected feed chemical composition and growth performance and feed utilization of sex-reversed Nile tilapia, Oreochromis niloticus (L.). Aquac Res 48: 1836-1848.

Selman W, Qualls C, Owen JO. 2013. Effects of human disturbance on the behavior and physiology of an imperiled freshwater turtle. $J$ Wildl Manag 77: 877-885.

Thongprajukaew K, Kanghae H, Kittiwattanawong K. 2016. Faecal characteristics as markers of Chelonia mydas feeding. Science Asia 42: 237-246.

Tidwell J, Coyle S, Bright LA. 2015. Effect of feed pellet characteristics on growth and feed conversion efficiency of largemouth bass raised in ponds. $N$ Am J Aquac 77: 55-58.

Wang CC, Huang CH. 2015. Effects of dietary vitamin C on growth, lipid oxidation, and carapace strength of soft-shelled turtle, Pelodiscus sinensis. Aquaculture 445: 1-4.

Wilson RP. 1994. Utilization of dietary carbohydrate by fish. Aquaculture 124: 67-80.

Winkler UK, Stuckmann M. 1979. Glycogen, hyaluronate and some other polysaccharides greatly enhance the formation of exolipase by Serratia marcescens. J Bacteriol 138: 663-670.

WSPA. 2012. The Cayman turtle farm: a case for change. London: WSPA International.

Xian L, Ying L, Blancheton JP. 2013. Effect of stocking density on performances of juvenile turbot (Scophthalmus maximus) in recirculating aquaculture systems. Chin J Oceanol Limnol 31: 514-522.

Zhang F, Gu H, Li P. 2011. A review of chelonian hematology. Asian Herpetol Res 2: 12-20.

Zhou F, Ding X-y, Feng H, et al. 2013. The dietary protein requirement of a new Japanese strain of juvenile Chinese soft shell turtle, Pelodiscus sinensis. Aquaculture 412-413: 74-80.

Cite this article as: Songnui A, Thongprajukaew K, Kanghae H, Satjarak J, Kittiwattanawong K. 2017. Water depth and feed pellet type effects on growth and feed utilization in the rearing of green turtle (Chelonia mydas Linnaeus, 1758). Aquat. Living Resour. 30 : 18 